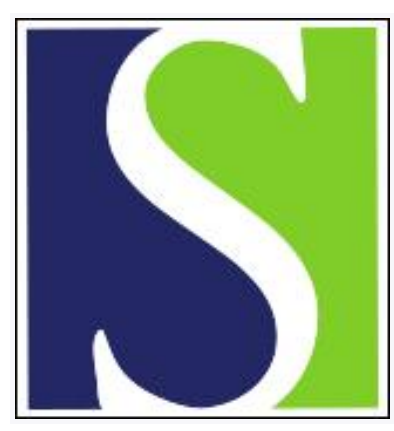

Scand J Work Environ Health 1979;5(1):23-30

https://doi.org/10.5271/sjweh.2669

Issue date: Mar 1979

\title{
Evaluation of heat stress during sedentary work.
}

by Ljungberg A-S, Enander A, Holmer I

Key terms: body temperature; comfort perception; heart rate; heat; heat stress; mean skin temperature; sedentary work; stress; sweat rate; temperature perception; work

This article in PubMed: www.ncbi.nlm.nih.gov/pubmed/441706

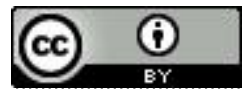




\title{
Evaluation of heat stress during sedentary work
}

\author{
by ANN-SOFIE LJUNGBERG, M.Sc., ANN ENANDER, M.A., \\ and INGVAR HOLMÉR, Ph.D. ${ }^{1}$
}

\begin{abstract}
LJUNGBERG, A.-S., ENANDER, A. and HOLMER, I. Evaluation of heat stress during sedentary work. Scand. j. work environ. \& health 5 (1979) 23-30. The aim of the investigation was to study physiological effects and subjective experience during sedentary work in two different climates (air temperature $40^{\circ} \mathrm{C}$ and relative humidity $40 \%$, and $32{ }^{\circ} \mathrm{C}$ and $80 \%$, respectively). Four men and four women, all unacclimatized and of normal body weight and height, participated in the study. Each subject was exposed to both climate conditions for $90 \mathrm{~min}$. Body temperature, skin temperature, heart rate, and body weight loss were measured continuously. At certain intervals during exposure subjects rated perceived temperature and comfort. Significant differences in the physiological reactions to the two conditions were observed. Heart rate, mean skin temperature and sweat rate were higher under the $40^{\circ} \mathrm{C}$ temperature conditions than at $32^{\circ} \mathrm{C}$. The mean rise in body temperature was approximately $0.2-0.3^{\circ} \mathrm{C}$. All subjects rated the climate at $40^{\circ} \mathrm{C}$ as warmer and more uncomfortable than at $32^{\circ} \mathrm{C}$. During the last half hour of exposure, air velocity was increased with the aid of a fan. This action increased the heat loss at $32^{\circ} \mathrm{C}$ and resulted in a decrease in mean skin temperature although body temperature mainly remained unchanged. The increased air velocity had a positive effect on perceived comfort. The men had a higher sweat rate and reported more discomfort than the women. Indices such as the Swedish wet-bulb globe temperature and corrected effective temperature did not discriminate between the two climates, but they yielded lower values with decreased air velocity. On the other hand, indices based on heat balance analysis or calculations of sweat rate (heat stress index, predicted 4-h sweat rate and effective temperature) could more accurately predict the physiological and psychological strain.
\end{abstract}

Key words: body temperature, comfort perception, heart rate, heat stress, mean skin temperature, sweat rate, temperature perception, thermal index.

Heat stress has an adverse effect on bodily functions and work capacity. A large number of studies have been performed and measures have been adopted in order to test different types of heat indices for the assessment of the effect of heat (4, 8, 13). Physical work capacity declines

1 Occupational Health Department, National Board of Occupational Safety and Health, Stockholm, Sweden.

Reprint requests to: Dr. Ingvar Holmér, National Board of Occupational Safety and Health, S-10026 Stockholm, Sweden. considerably in a hot environment, especially in conjunction with a high physical work load. Severe heat stress, even in jobs with a low level of physical activity such as sedentary office work, affects work capacity in different ways $(11,16)$. The objective of the present study was to examine physiological effect and perception during sedentary work in hot and dry and hot and humid climates, respectively. A simultaneous objective was to assess the merit of using some heat stress indices for this type of work. 


\section{MATERIAL AND METHODS}

\section{Subjects}

The study comprised four female and four male subjects. The women were between 28 and 46 years of age with a height of $162-170 \mathrm{~cm}$ and a weight of $53-63 \mathrm{~kg}$. The men were between 22 and 32 years of age with a height of $172-179 \mathrm{~cm}$ and a weight of $60-82 \mathrm{~kg}$. All of the subjects had physically undemanding jobs, and none of them were more acclimatized to heat than could be expected at the time of the year (August) and under the prevailing weather conditions (mainly sunny and warm) at the time of testing. All of the subjects were healthy at the time of the study, and none of them had previously suffered from any serious disorder of the circulatory or respiratory organs.

\section{Types of climate}

Each subject was exposed for $90 \mathrm{~min}$ to a climate with an air temperature of $32^{\circ} \mathrm{C}$ and a relative humidity of $80 \%$ and to a climate with an air temperature of $40^{\circ} \mathrm{C}$ and a relative humidity of $40 \%$. The mean radiant temperature was equal to the air temperature. These two types of climate will henceforth be referred to by the prevalent air temperature, i.e., $32^{\circ} \mathrm{C}$ and $40^{\circ} \mathrm{C}$. Air velocity was identical in the two experiments and was kept constant at $0.1-0.2 \mathrm{~m} / \mathrm{s}$ during the initial hour of exposure. The temperature and climate were selected so that both climates corresponded to an index value of about $32^{\circ} \mathrm{C}$ SWBGT. [SWBGT $=$ Swedish wet-bulb globe temperature $=0.7 \times \mathrm{t}_{\mathrm{w}}+$ $0.3 \times t_{g}$, where $t_{w}=$ psychrometric wet temperature in degrees centigrade and $t_{\mathrm{g}}=$ globe temperature in degrees centigrade. When air velocity is $<0.5 \mathrm{~m} / \mathrm{s}$, $2{ }^{\circ} \mathrm{C}$ are added (1).] During the final half hour of exposure, under both conditions, the air velocity around the subject was increased to $0.5-2 \mathrm{~m} / \mathrm{s}$ with the aid of an oscillating table fan. Both of these climate types were then equivalent to about $30^{\circ} \mathrm{C}$ SWBGT.

\section{Experimental design}

The two experiments were performed in the morning or early afternoon on different days. The sequence of climate conditions was varied systematically. Each measurement session was preceded by half an hour of preparations at room temperature $\left(22-24^{\circ} \mathrm{C}\right)$. Each subject received information on the study and instructions on the procedure. They were dressed in standardized clothing giving about 0.6 clo, i.e., long white cotton slacks, a short-sleeved cotton T-shirt, underpants and socks.

Throughout the $90 \mathrm{~min}$ of exposure the subject sat reading in the climate chamber. Recordings of body temperature, skin temperature and heart rate were carried out for $60 \mathrm{~s}$ every other minute. The weight of each subject, including clothing, was registered prior to the start of exposure and after $5,15,30,45,60,65,75$ and $90 \mathrm{~min}$, at which times subjects also rated perceived temperature and comfort.

\section{Measurement methods}

Exposure was carried out in a climate chamber with a controlled air temperature $\left( \pm 0.5^{\circ} \mathrm{C}\right)$ and relative humidity ( $\pm 2.5 \% \mathrm{RH})$. Measurement values were collected via a 24-channel A-D converter and multiplexer unit. They were recorded and processed by a central measurement unit built up around a minicomputer, the Alpha LSI-2.

Body temperature $\left(\mathrm{T}_{\mathrm{zu}}\right)$ was measured in the auditory canal at the ear drum with a linear thermistor $\left( \pm 0.1^{\circ} \mathrm{C}\right)$ built into ear muffs (12) (Zero Gradient Ear Thermometer, Muirhead Ltd., Beckenham, England). Body temperature $\left(\mathrm{T}_{\mathrm{re}}\right)$ was also measured, with an ordinary rectal thermometer, before and after the experiment. Skin temperature $\left(\mathrm{T}_{\mathrm{sk}}\right)$ was determined with linear thermistors (accuracy $\pm 0.2^{\circ} \mathrm{C}$ ) taped to the subject's forehead, chest, back, abdomen, thigh, lower leg, upper arm and forearm. The mean temperature $\left(T_{s k}\right)$ was calculated according to Crawshaw et al. (3) as the weighted mean value of the temperature at these measurement points. Heart rate was recorded via chest electrodes and a 
cardiometer (Cardiometer, Cardionics $\mathrm{AB}$, Stockholm). The sweat rate was calculated on the basis of the amount of evaporated sweat as determined by the clothed subject's change in weight during the experiment. The subject sat on a chair placed on a scale platform for the electronic assessment of weight (accuracy $\pm 5 \mathrm{~g}$ ).

The subjects rated perceived temperature and comfort using numbered assessment scales, with verbal definitions according to Gagge et al. (9), as follows:

$\begin{array}{ll}\text { Temperature } & \begin{array}{l}\text { Comfort } \\ 1 \\ 2 \text { Cold }\end{array} \\ 3 \text { Comfortable } \\ 4 \text { Cool } & 2 \text { Slightly uncomfortable } \\ 5 & 3 \text { Uncomfortable } \\ 6 \text { Slightly cool } & \\ 7 & 4 \text { Very uncomfortable } \\ 8 \text { Neutral } & \\ 9 & \\ 10 \text { Slightly warm } & \\ 11 & \\ 12 \text { Warm } & \\ 13 \\ 14 \text { Hot }\end{array}$

A statistical analysis was made of the values after 60 and $90 \mathrm{~min}$, respectively, for the following variables: heart rate, $\mathrm{T}_{\mathrm{au}}, \overline{\mathrm{T}}_{\mathrm{sk}}$, temperature rating, and comfort rating. A three-way analysis of variance model with repeated measurement on two factors was used (18). Sex, type of climate, and air velocity constituted the three sources of variation.

\section{RESULTS}

Table 1 lists the mean values and standard deviations for variables recorded in the two types of climate both for men and women separately and for all eight subjects combined. The statistical analysis is summarized in table 2. Fig. 1 provides examples of individual response patterns.

Heart rate during exposure generally stabilized at a relatively constant level. This level was significantly higher at $40^{\circ} \mathrm{C}$ than at $32^{\circ} \mathrm{C}(\mathrm{p}<0.05)$. The mean heart rates amounted to 87 and 81 beats/ $\mathrm{min}$, respectively, after $60 \mathrm{~min}$ and to 88 and 79 beats/min, respectively, after 90 min. Air velocity had no significant effect on heart rate. Individual heart rates ranged from 63 to 115 beats $/ \mathrm{min}$. Intraindividual variations in heart rate under the different conditions can be seen in fig. 2.

$\mathrm{T}_{\mathrm{au}}$ and $\mathrm{T}_{\mathrm{sk}}$ generally remained constant during the latter part of each period of exposure. $T_{r e}$ increased, on an average, $0.3^{\circ} \mathrm{C}$ under the $40^{\circ} \mathrm{C}$ temperature conditions and $0.2^{\circ} \mathrm{C}$ under the $32^{\circ} \mathrm{C}$ temperature conditions and amounted to 37.3 and $37.2{ }^{\circ} \mathrm{C}$, respectively, after the $90-\mathrm{min}$ exposure. In the analysis of variance a tendency towards interaction between sex and type of climate for $\mathrm{T}_{\mathrm{au}}(\mathrm{p}<0.10)$ was found. The women had a somewhat higher $\mathrm{T}_{\mathrm{au}}$ than the men at $40^{\circ} \mathrm{C}$.

$\overrightarrow{\mathrm{T}}_{\mathrm{sk}}$ (fig. 2) was significantly higher at an air temperature of $40^{\circ} \mathrm{C}$ than at $32^{\circ} \mathrm{C}$ $(p<0.001)$ and rose to mean values of $37^{\circ} \mathrm{C}$ and $35.9^{\circ} \mathrm{C}$, respectively, after 60 min. A significant effect of air velocity $(p<0.01)$ and a significant interaction between air velocity and type of climate $(p<0.001)$ were disclosed by an analysis of variance. Increased air velocity had a relatively slight effect on $\overline{\mathrm{T}}_{\mathrm{sk}}$ at $40^{\circ} \mathrm{C}$, while a mean drop of $0.4^{\circ} \mathrm{C}$ was measured in the final 30 min of exposure in an air temperature of $32^{\circ} \mathrm{C}$. The analysis also disclosed a significant three-factor interaction between sex, air velocity and type of climate $(p<0.05)$. On the average, the women had a somewhat higher $\overline{\mathrm{T}}_{\mathrm{sk}}$ than the men after $60 \mathrm{~min}$ at $40^{\circ} \mathrm{C}$.

The sweat rate during exposure is shown in table 1 . It corresponded to $163 \mathrm{~g} / \mathrm{h}$ within the first $60 \mathrm{~min}$ and to $229 \mathrm{~g} / \mathrm{h}$ during the final half-hour in an air temperature of $40^{\circ} \mathrm{C}$. The corresponding values at $32^{\circ} \mathrm{C}$ were $58 \mathrm{~g} / \mathrm{h}$ and $63 \mathrm{~g} / \mathrm{h}$. There was a distinct difference between the sexes in both types of climate. The men always displayed a greater sweat rate than the women and therefore displayed a greater weight loss during exposure (fig. 3). This phenomenon is in line with the results of previous investigations $(2,7,14)$. 
There was a significant difference be- $(p<0.001$ and $p<0.05$, respectively). tween climate types (table 2) for both Subjects consistently found conditions at temperature and comfort perception $40^{\circ} \mathrm{C}$ more uncomfortable than at $32^{\circ} \mathrm{C}$.

Table 1. Mean skin temperature $\left(\overline{\mathrm{T}}_{\mathrm{sk}}\right)$, body temperature ( $\left.\mathrm{T}_{\mathrm{au}}\right)$, sweat rate (SR) and heart rate $(\mathrm{HR})$ of four women and four men after 60 and $90 \mathrm{~min}$ of sedentary work under the 32 and $40^{\circ} \mathrm{C}$ temperature conditions. The increase in rectal temperature $\left(\triangle \mathrm{T}_{\mathrm{re}}\right)$ over the measurement period is also given. The means and standard deviations are stated.

\begin{tabular}{|c|c|c|c|c|c|c|}
\hline \multirow{2}{*}{ Parameter } & \multicolumn{2}{|c|}{ Women } & \multicolumn{2}{|c|}{ Men } & \multicolumn{2}{|c|}{ Total } \\
\hline & $32^{\circ} \mathrm{C}$ & $40^{\circ} \mathrm{C}$ & $32^{\circ} \mathrm{C}$ & $40^{\circ} \mathrm{C}$ & $32^{\circ} \mathrm{C}$ & $40^{\circ} \mathrm{C}$ \\
\hline \multicolumn{7}{|c|}{$\mathrm{T}_{\mathrm{sk}}\left({ }^{\circ} \mathrm{C}\right), 60 \mathrm{~min}$} \\
\hline $\begin{array}{l}\text { Mean } \\
\text { SD }\end{array}$ & $\begin{array}{r}35.9 \\
0.4\end{array}$ & $\begin{array}{r}37.1 \\
0.4\end{array}$ & $\begin{array}{r}35.9 \\
0.3\end{array}$ & $\begin{array}{r}36.8 \\
0.4\end{array}$ & $\begin{array}{r}35.9 \\
0.3\end{array}$ & $\begin{array}{r}37.0 \\
0.4\end{array}$ \\
\hline \multicolumn{7}{|c|}{$\mathrm{T}_{\mathrm{sk}}\left({ }^{\circ} \mathrm{C}\right), 90 \mathrm{~min}$} \\
\hline $\begin{array}{l}\text { Mean } \\
\mathrm{SD}\end{array}$ & $\begin{array}{r}35.4 \\
0.3\end{array}$ & $\begin{array}{r}37.0 \\
0.4\end{array}$ & $\begin{array}{r}35.5 \\
0.2\end{array}$ & $\begin{array}{r}36.9 \\
0.4\end{array}$ & $\begin{array}{r}35.5 \\
0.2\end{array}$ & $\begin{array}{r}37.0 \\
0.4\end{array}$ \\
\hline \multicolumn{7}{|c|}{$\mathrm{T}_{\mathrm{au}}\left({ }^{\circ} \mathrm{C}\right), 60 \mathrm{~min}$} \\
\hline $\begin{array}{l}\text { Mean } \\
\text { SD }\end{array}$ & $\begin{array}{r}37.1 \\
0.1\end{array}$ & $\begin{array}{r}37.5 \\
0.2\end{array}$ & $\begin{array}{r}37.2 \\
0.3\end{array}$ & $\begin{array}{r}37.1 \\
0.2\end{array}$ & $\begin{array}{r}37.1 \\
0.2\end{array}$ & $\begin{array}{r}37.3 \\
0.3\end{array}$ \\
\hline \multicolumn{7}{|c|}{$\mathrm{T}_{\mathrm{au}}\left({ }^{\circ} \mathrm{C}\right), 90 \mathrm{~min}$} \\
\hline $\begin{array}{l}\text { Mean } \\
\text { SD }\end{array}$ & $\begin{array}{r}37.2 \\
0.1\end{array}$ & $\begin{array}{r}37.4 \\
0.3\end{array}$ & $\begin{array}{r}37.2 \\
0.3\end{array}$ & $\begin{array}{r}37.2 \\
0.2\end{array}$ & $\begin{array}{r}37.2 \\
0.2\end{array}$ & $\begin{array}{r}37.3 \\
0.3\end{array}$ \\
\hline \multicolumn{7}{|c|}{$\Delta \mathrm{T}_{\mathrm{re}}\left({ }^{\circ} \mathrm{C}\right), 0-90 \mathrm{~min}$} \\
\hline $\begin{array}{l}\text { Mean } \\
\mathrm{SD}\end{array}$ & $\begin{array}{r}0.1 \\
0.2\end{array}$ & $\begin{array}{r}+0.3 \\
0.2\end{array}$ & $\begin{array}{r}+0.2 \\
0.2\end{array}$ & $\begin{array}{r}+0.3 \\
0.1\end{array}$ & $\begin{array}{r}+0.2 \\
0.2\end{array}$ & $\begin{array}{r}+0.3 \\
0.2\end{array}$ \\
\hline \multicolumn{7}{|c|}{$\mathrm{SR}(\mathrm{g} / \mathrm{h}), 0-60 \mathrm{~min}$} \\
\hline $\begin{array}{l}\text { Mean } \\
\text { SD }\end{array}$ & $\begin{array}{l}21 \\
13\end{array}$ & $\begin{array}{r}121 \\
7\end{array}$ & $\begin{array}{l}85 \\
31\end{array}$ & $\begin{array}{r}194 \\
41\end{array}$ & $\begin{array}{l}58 \\
41\end{array}$ & $\begin{array}{r}163 \\
49\end{array}$ \\
\hline \multicolumn{7}{|c|}{$\mathrm{SR}(\mathrm{g} / \mathrm{h}), 60-90 \mathrm{~min}$} \\
\hline $\begin{array}{l}\text { Mean } \\
\text { SD }\end{array}$ & $\begin{array}{l}43 \\
51\end{array}$ & $\begin{array}{r}183 \\
49\end{array}$ & $\begin{array}{l}80 \\
71\end{array}$ & $\begin{array}{r}263 \\
20\end{array}$ & $\begin{array}{l}63 \\
61\end{array}$ & $\begin{array}{r}229 \\
53\end{array}$ \\
\hline \multicolumn{7}{|c|}{ HR (beats $/ \mathrm{min}$ ), $60 \mathrm{~min}$} \\
\hline $\begin{array}{l}\text { Mean } \\
\text { SD }\end{array}$ & $\begin{array}{r}87 \\
8\end{array}$ & $\begin{array}{l}96 \\
10\end{array}$ & $\begin{array}{l}74 \\
10\end{array}$ & $\begin{array}{l}78 \\
16\end{array}$ & $\begin{array}{l}81 \\
11\end{array}$ & $\begin{array}{l}87 \\
15\end{array}$ \\
\hline \multicolumn{7}{|c|}{$\mathrm{HR}$ (beats $/ \mathrm{min}$ ), $90 \mathrm{~min}$} \\
\hline $\begin{array}{l}\text { Mean } \\
\text { SD }\end{array}$ & $\begin{array}{r}85 \\
8\end{array}$ & $\begin{array}{l}95 \\
15\end{array}$ & $\begin{array}{r}73 \\
8\end{array}$ & $\begin{array}{l}82 \\
15\end{array}$ & $\begin{array}{l}79 \\
10\end{array}$ & $\begin{array}{l}88 \\
15\end{array}$ \\
\hline
\end{tabular}

Table 2. F ratios obtained in the analysis of variance of heart rate (HR), body temperature $\left(T_{\mathrm{au}}\right)$, mean skin temperature $\left(\overline{\mathrm{T}}_{\mathrm{sk}}\right)$, perceived temperature $\left(\mathrm{P}_{\mathrm{T}}\right)$ and perceived comfort $\left(\mathrm{P}_{\mathrm{C}}\right)$. The degrees of freedom are 1 and 6 throughout.

\begin{tabular}{lccccc}
\hline Source of variation & $\mathrm{HR}$ & $\mathrm{T}_{\mathrm{au}}$ & $\mathrm{T}$ sk & $\mathrm{P}_{\mathrm{T}}$ & $\mathrm{P}_{\mathrm{C}}$ \\
\hline Sex (S) & 3.31 & 1.12 & $<1$ & $<1$ & $<1$ \\
Type of climate (C) & $11.04^{*}$ & 3.14 & $72.60^{* * *}$ & $54.55 * * *$ & $8.00^{*}$ \\
Air velocity (A) & $<1$ & 2.35 & $<5.68 * *$ & 3.95 & $9.00^{*}$ \\
S $\times$ C & $<1$ & 5.09 & $<1$ & 4.91 & 2.00 \\
S $\times$ A & 1.21 & 1.04 & $<1$ & 1.42 & $<1.00$ \\
C $\times$ A & 1.39 & 1.60 & $50.00^{* * *}$ & $<1$ & $<1$ \\
S $\times$ C $\times$ A & $<1$ & $<1$ & $8.00^{*}$ & 3.86 & $<1$ \\
\hline
\end{tabular}

$* \mathrm{p}<0.05 ; * * \mathrm{p}<0.01 ; * * * \mathrm{p}<0.001$. 


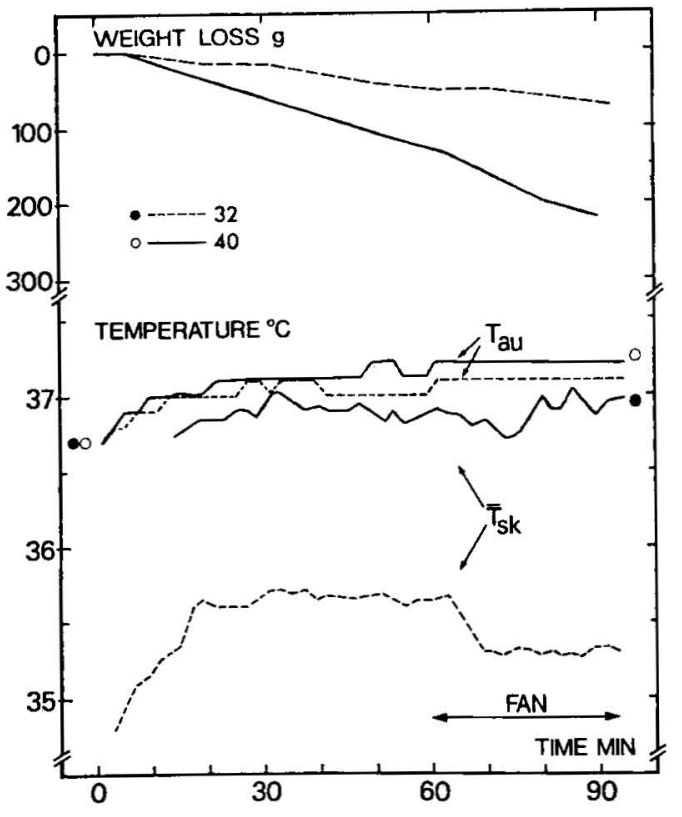

Fig. 1. Weight loss, mean skin temperature $\left(\overline{\mathrm{T}}_{\mathrm{sk}}\right)$ and body temperature $\left(\mathrm{T}_{\mathrm{au}}\right)$ measured continuously for one male subject during 90 min of exposure to the 32 and $40^{\circ} \mathrm{C}$ temperature conditions. Rectal temperature (-0) before and after each experiment is also shown.
Thus the temperature was perceived as "warm" or "hot" (rating $11-15$ ) at $40^{\circ} \mathrm{C}$ and "neutral" to "warm" (rating 7-12) at $32{ }^{\circ} \mathrm{C}$ (fig. 4). The corresponding assessment for comfort was "uncomfortable" (about 3) and "slightly uncomfortable" (about 2).

Most subjects found the climate more comfortable during the final half hour, i.e., after the fan was turned on. This change was reflected by the significant difference in comfort perception between conditions with and without the fan $(\mathrm{p}<0.05)$. There was a corresponding difference in temperature perception, which did not, however, reach significance. There was a slight difference between the sexes at $40^{\circ} \mathrm{C}$, and on the average the women found the climate to be warmer than the men did. It should be noted that the women had a higher average $T_{a u}$ than the men in this type of climate. There was no difference in comfort perception at $40^{\circ} \mathrm{C}$. The sexes did not differ in temperature perception at $32{ }^{\circ} \mathrm{C}$ although the men tended to experience greater discomfort than the women.
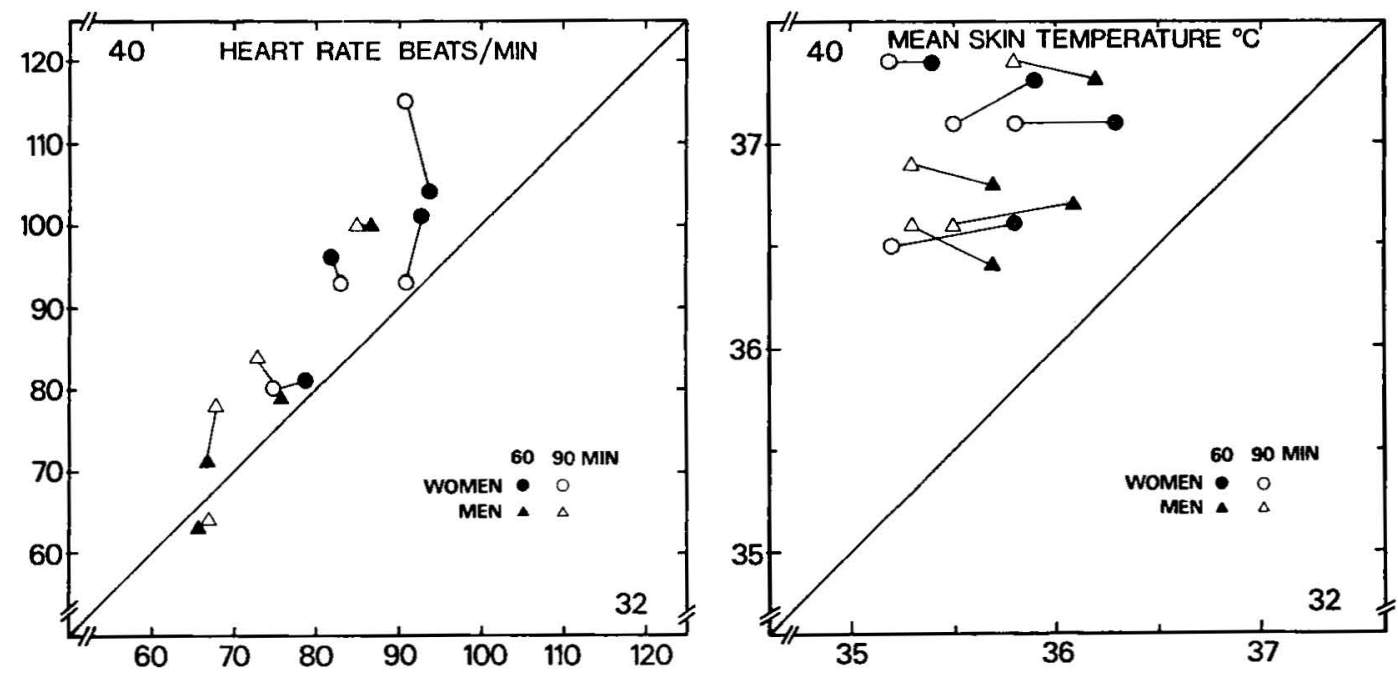

Fig. 2. Heart rate and mean skin temperature measured for each subject after 60 and 90 min of exposure to the 32 and $40^{\circ} \mathrm{C}$ temperature conditions. 


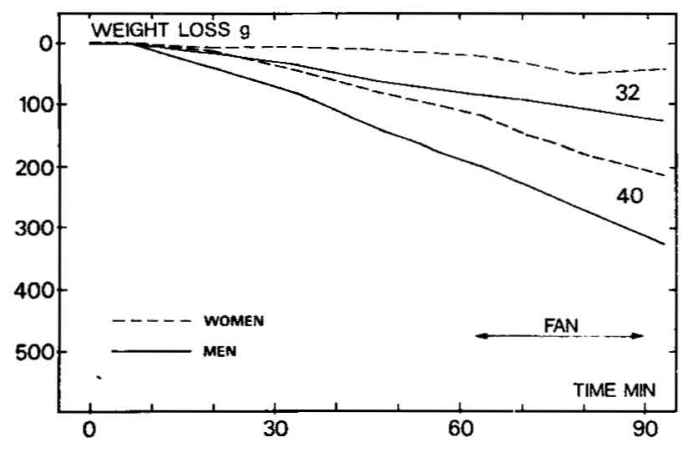

Fig. 3. Weight loss (g) of the men and women during $90 \mathrm{~min}$ of exposure to the 32 and $40^{\circ} \mathrm{C}$ temperature conditions.
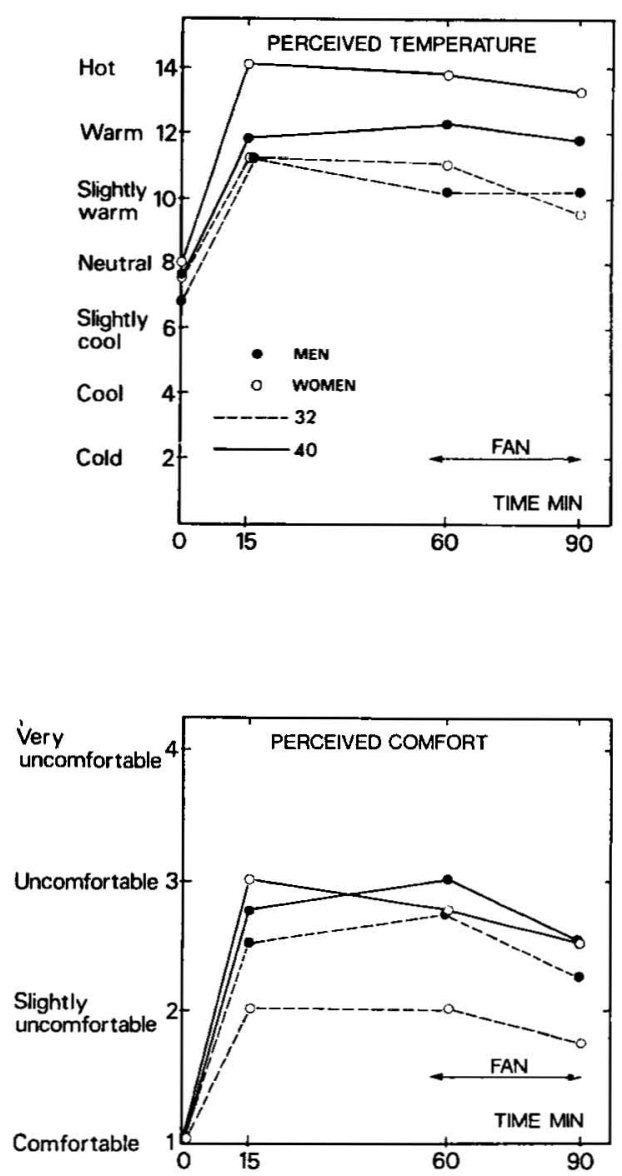

Fig. 4. Perceived temperature and comfort. Mean values for the men and women after 0 , 15,60 and $90 \mathrm{~min}$ of exposure to the 32 and $40^{\circ} \mathrm{C}$ temperature conditions.

\section{DISCUSSION}

The types of climate examined in the present study greatly exceeded the comfort zone normally associated with sedentary office work by people dressed in light clothing (5). In the summer, however, climate and local conditions at such work sites may result in severe heat stress.

The humidity of the air is of great importance in the response to a climate with a high air temperature. As a rule, high humidity is felt to be more uncomfortable than low humidity at a given temperature (15). Heat indices integrate the various factors of thermal climate (air temperature, radiation temperature, atmospheric humidity and air velocity) in such a manner that the anticipated physiological effect on man at a given index value should be more or less the same, irrespective of the values of the individual factors. However, the usefulness and reliability of a heat index varies under different conditions as a consequence of its construction and definition. Some heat indices are based on the analysis of heat exchange [heat stress index (HSI), effective temperature (ET*)], while others have a more empirical background [corrected effective temperature (CET), Swedish wet-bulb globe temperature (SWBGT), predicted 4-h sweat rate (P4SR)]. For definitions of the various indices the reader is referred to other publications $(1,8,13)$.

Both types of climate studied yielded a SWBGT value corresponding to about $32^{\circ} \mathrm{C}$ and a $\mathrm{CET}$ value of about $30^{\circ} \mathrm{C}$, although both physiological strain and perception differed greatly under the two different conditions. An assessment of the effect of heat stress on the body's heat balance showed that the conditions at $40^{\circ} \mathrm{C}$ had a much greater effect. This situation was the most apparent from the sweat rate which, on the average, was twice as great for men and six times greater for women at $40^{\circ} \mathrm{C}$ than at $32^{\circ} \mathrm{C}$ after $60 \mathrm{~min}$ of exposure. Both HSI, P4SR and ET* could satisfactorily distinguish between the climate types at low air velocities, and they yielded values of heat stress which were more severe for the $40^{\circ} \mathrm{C}$ environment. This phenom- 
enon is not surprising since all three indices, by their construction, give greater consideration to the evaporative heat transfer from the body. The HSI value also decreased as a result of increased air velocity.

Atmospheric humidity as high as $80 \%$ seems to be sufficient to satisfactorily evaporate sweat from the skin at an air temperature of $32^{\circ} \mathrm{C}$ in sedentary work with a relatively low sweat rate (less than $0.2 \mathrm{l} / \mathrm{h}$ ). Heavy work in hot industry has been reported to induce sweat rates ranging from $0.5-1.0 \mathrm{l} / \mathrm{h}$ or more. Under these conditions humidity is of great importance to the degree of physiological strain involved. This is probably the most important reason why heat indices, which are largely based on wet temperature, are of limited usefulness when applied to sedentary work (13).

The higher air velocity after $60 \mathrm{~min}$ at $32^{\circ} \mathrm{C}$ facilitated heat release by both convection and sweating. $T_{\mathrm{sk}}$ also decreased by an average of $0.4^{\circ} \mathrm{C}$. The higher air velocity at $40^{\circ} \mathrm{C}$ could entail somewhat greater heat stress and thereby make increased sweating necessary. However, the increase observed (from $163 \mathrm{~g} / \mathrm{h}$ to $229 \mathrm{~g} / \mathrm{h}$ ) can also be explained by the facilitated evaporation of sweat from the surface of the skin caused by the increased air velocity. There was no striking change in either $T_{a n}$ or $T_{\text {sk }}$ between 60 and $90 \mathrm{~min}$ at $40^{\circ} \mathrm{C}$. All of the indices, except the P4SR at $40^{\circ} \mathrm{C}$, predicted less heat stress as a result of increased air velocity. The P4SR yielded the same value at $40^{\circ} \mathrm{C}$ irrespective of air velocity, and this result was more in line with the physiological reactions of our subjects.

The small increase in $\mathrm{T}_{\mathrm{re}}\left(0.2-0.3^{\circ} \mathrm{C}\right)$ and the low absolute level $\left(37.5^{\circ} \mathrm{C}\right.$ in women and $37.2^{\circ} \mathrm{C}$ in men) after $90 \mathrm{~min}$ of exposure would suggest rather modest physiological strain. On the other hand, if the measured sweat rate is identified as required sweat rate $\left(\mathrm{E}_{\mathrm{ren}}\right)$ and it is compared with the maximum evaporative capacity of the environment $\left(\mathrm{E}_{\max }\right)$, the picture is a different one. The ratio $\mathrm{E}_{\mathrm{ref}} / \mathrm{E}_{\max }$ is the definition of the skin wetedness $(\mathrm{w})$ and has been shown to correlate well with heat discomfort (10). With this approach the conditions at $40^{\circ} \mathrm{C}$ at low air velocities would present great heat stress with a ratio of about 0.8 . Under the other conditions the predicted heat stress was more moderate. Our values for the female subjects were consistently lower than those for the males, as a result of their lower sweat rates, and they suggest a milder heat stress. This result was supported by the comfort votes. The men tended to feel greater discomfort from heat than the women.

$\left(\mathrm{E}_{\mathrm{req}} / \mathrm{E}_{\max }\right) \times 100$ is also the classical definition of HSI, with equations given for the calculation of both $\mathrm{E}_{\text {req }}$ and $\mathrm{E}_{\max }$. Our values compared favorably with the calculated HSI values.

The utilization of subjective scales has previously proved to be a useful method for comparing and ranking different climatic conditions, and good correlations with physiological data have been obtained (6). In the present study, the ratings of temperature and comfort disclosed clear differences in the perception of the two types of climate. At $40^{\circ} \mathrm{C}$ the climate was always regarded as being hotter and more uncomfortable than at $32^{\circ} \mathrm{C}$, as also reflected by the physiological measurements. The subjects were also capable of making a distinction between the perception of temperature and the perception of comfort. Thus, increased air flow resulted in a significant improvement in climate from the comfort point of view, whereas the change in temperature perception was less striking.

The present study disclosed that the sexes tended to differ with respect to temperature perception. This difference could be explained to some extent by an actual difference in $T_{a u}$ at the time of the experiments. Moreover, the men tended to feel greater discomfort from heat than the women. A number of studies have found a clear correlation between heat discomfort and sweating intensity, especially skin wetedness (10). On the other hand, the perception of temperature appeared to be better correlated to skin and ambient temperature. Thus the greater sweating intensity of the men in this study may have contributed to the greater discomfort felt by them. The results can also be compared to the sexual differences found by Rohles (17) 
in a study of the temperature preferences of young men and women in sedentary work. During the first $90 \mathrm{~min}$ he found that men preferred a significantly lower ambient temperature for optimum comfort than women.

To summarize, there is a clear difference in both physiological and psychological strain during sedentary work in a climate with an air temperature of $40^{\circ} \mathrm{C}$ and $40 \%$ relative humidity in comparison to a climate of $32{ }^{\circ} \mathrm{C}$ and $80 \%$ relative humidity. Although both can be approximately characterized by the same index value expressed in SWBGT or CET, our data suggest a higher heat stress in the $40^{\circ} \mathrm{C}$ environment. Especially under conditions of low air velocity this climate would be very stressful. The best indicator of the actual strain appeared to be the sweat rate, especially when expressed as skin wettedness. Indices based on heat balance analysis or calculations of sweat rate could be used to predict actual heat stress.

\section{ACKNOWLEDGMENTS}

The authors extend their warmest thanks to all the subjects for their participation in the study and for their persistence with the, perhaps not heavy, but sweaty work. We especially wish to acknowledge Ms. Maj-Britt Cedervall for also typing the manuscript.

\section{REFERENCES}

1. AXELSSON, O., ERIKSSON, U., OLANDER, L., REHN, M. and ASTRAND, I. Värmebelastning $i$ yrkesarbete - bedömningsgrunder och mätteknik (Arbete och hälsa no. 2). Arbetarskyddsverket, Stockholm 1974. $65 \mathrm{p}$.
2. BITTEL, J. and HENANE, R. Comparison of thermal exchanges in men and women under neutral and hot conditions. J. physiol. 250 (1975) 475-489.

3. CRAWSHAW, L. I., NADEL, E. R., STOLWIJK, J. A. J. and STAMFORD, B. A. Effect of local cooling on sweating rate and cold sensation. Pflügers Arch. 354 (1975) $19-27$.

4. DUKE-DOBOS, F. and HENSCHEL, A. Development of permissible heat exposure limits for occupational work. ASHRAE $j$. September (1973) 57-62.

5. FANGER, P. O. Thermal comfort. Danish Technical Press, Copenhagen 1970. 244 p.

6. FINE, B. J. The comparative effectiveness of some psychological and physiological measures in ranking the impact of diverse environmental conditions. J. appl. psychol. 42 (1958): $5,353-356$.

7. FOX, R. H., LÖFSTEDT, B. E., WOODWARD, P. M., ERIKSSON, E. and WERKSTROM, B. Comparison of thermoregulatory function in men and women. J. appl. physiol. 26 (1969): 4, 444-453.

8. GAGGE, A. P. and NISHI, Y. Physical indices of the thermal environment. ASHRAE j. January (1976) 47-51.

9. GAGGE, A. P., STOLWIJK, F, A. J. and HARDY, J. D. Comfort and thermal sensations and associated physiological responses at various ambient temperatures. Environ. res. 1 (1967) 1-20.

10. GAGGE, A. P., STOLWIJK, J. A. J. and SALTIN, B. Comfort and thermal sensations and associated physiological responses during exercise at various ambient temperatures. Environ. res. 2 (1969): 3, 209-229.

11. GRETHER, W. F. Human performance at elevated environmental temperatures. Aerosp. med. 44 (1973): 7, 747-755.

12. KEATINGE, W. R. and SLOAN, R. E. G Deep body temperature from aural canal with servocontrolled heating to outer ear. J. appl. physiol. 38 (1975); 5, 919-921.

13. KERSLAKE, M. M. The stress of hot environments. Cambridge University Press, Cambridge 1972. $316 \mathrm{p}$

14. LOFSTEDT, B. Human heat tolerance. Berlingske Boktryckeriet, Lund 1966. 106 p.

15. MC INTYRE, D. A and GRIFFTTHS, I. D. Subjective responses to atmospheric humidity. Environ. res. 9 (1975) 66-75.

16. RAMSEY, J. D., DAYAL, D. and GHAHRAMANI, B. Heat stress limits for the sedentary worker. Am. ind. hyg. assoc. $j$. April (1975) 259-265.

17. ROHLES, F. H. Thermal sensations of sedentary man in moderate temperatures. Hum. factors 13 (1971): 6, 553-560.

18. WINER, B. J. Statistical principles in experimental design. McGraw-Hill Book Co., New York, N.Y. 1970, pp. 319-337. 